\title{
correspondence
}

\section{"THE RELIGIOUS SITUATION IN EAST ASIA"}

Dear Sir:

Mandalay, Burma

Please excise the lateness of this comment, but I have jerst seen the article on which I feel I must comment.

Mr. Thomas Molnar's observations on East Asia, as published in the Jomary, 1965 issuc of world tiew; betray misconceptions on ecrtain issues. Such a thing, certainly, is to be expocted when a traveller, biased in favour of his own faith, proceeds to hasty conclusions without much regard for historical con. siderations and cultural and psychological backgrounds. The challenging situation his article has created with respect to religious life in East and Southeast Asia harms inter-religious understanding. However, for want of space, I intend limiting myself to certain brief observations on Buddhism and the future of Christianity in this region.

Reality, in the religious sense, is certainly far more complex in this part of the world than what would catch the eye or the mind of a tourist or foreign traveller. It is, as such, not unoften that conclusions are arrived at on the basis of illusions, with results unhappy and consequences serious. That Buddhism is spiritually exhausted and is actually fighting for survival is an assumption quite unwarranted. That it is "quite openly materialistic" is faulty enough to be obvious to anybody interested in truth.

-

"The impact of Christianity . . . brought two things to Asia which were unknown there and unknown particularly as a contribution of religion to society: dynamism in the social sphere and charity in the spiritual sphere," observes Mr. Molnar. While crediting Christianity for its "dynamism," which, however, not unoften went amok in history, and for its "charity," which not unoften was without charitable attitude to others, particularly in Asia, it needs be emphasized that "dynamism" and "charity" were not only known "as a contribution of religion to society" in Asia, but also known and practiced here to their best throughout the ages. While Buddhism has no truck with "dynamism" given to fanaticism, persecutions, and wars of destruction, it has ever been active for the well-being of society and for peace, happiness and healthy progress in the buman family. Long before Europe or America could drean of universities and hospitals, $A$ sia had these institutions in a very well organized form, particularly in India and Ceylon. Regarding orphanages, their existence is to be understood in the perspective of the Buddhist thouglt, which in the past regarded their presence as an insult to wholesome patterning of society. In Buddhist socicties, no sooncr one became an orphan, he or she was immediately adopted by relations, neighbors or friends as their own child and duly brought up. As such, the need of orphanages was out of question. Regarding education, Buddhism universalized it and democratized it: every village monastery had attached to it a school where besides the usual subjects and religious doctrines, the students had as well the advantage of civic and social duties instifled into them; and in the citics there were monastic universities for higher learning and research, where democratic practices were in evidence at their best in an atmosphere of purity and spiritual excellence.

The impact of Christianity, thongh a happy one in a minor way, was, frankly speaking, not a blessing but a curse on the whole. Most of the Christians who came were of the sub-mediocre brand, and besides given to drink and conceited outlook, with positively closed minds. The "bottle" and the "bible" were shortly found associated with colonization. There were in the bargain, from the Christian side, religious intolerance, political oppression, and social discrimination. No wonder, therefore, that Christianity as "an auxiliary force of white imperialism" has left a bad taste in many countries in this part of the world. It will be time before the wound heals.

Asia certainly is in ferment today. However, Mr. Molnar errs gricvously in characterizing "the civilization of Asia as almost empty shells." There are dynamic forces at work, material as well as spiritual, which are bound to march forward towards social stability, material well being and spiritual satisfaction. If Christianity learns to re-adjust to the changed conditions there will yet be a chance for it to serve in Asia in humility, not in conceit.

DR. L. L. SONI

Director Regional Centre, World Fellowship of Buddhists. 